\title{
PENINGKATAN PRESTASI BELAJAR FISIKA ZAT PADAT MAHASISWA NON-REGULAR MELALUI PEMBELAJARAN STAD DENGAN STRATEGI SELF-EXPLANATION
}

\author{
1) P a r n o \\ ${ }^{1)}$ Jurusan Fisika FMIPA Universitas Negeri Malang \\ e-mail: parno100@yahoo.co.id
}

\begin{abstract}
The aim of the study is to improve nonregular students' achievement on Solid State Physics course through the STAD model with Self-Explanation learning strategy. The study uses quasi-experimental with nonequivalent control group design. The result shows that the STAD model with SelfExplanation learning strategy can improve students' achievement. Experiment class attaines the normalized everage gain score of 0,567 (medium category), 0,783 (high category), and 0,465 (medium category) respectively for I, II, and final test. While control class attaines the normalized everage gain score of 0,366 (medium category), 0,391 (medium category), and 0,340 (medium category) respectively for I, II, and final test. In addition, experiment class students give higher positive response than control class for learning process.
\end{abstract}

Key words: STAD, Self-Explanation, achievement, Solid State Physics

\begin{abstract}
Abstrak
Penelitian ini bertujuan untuk meningkatkan prestasi belajar matakuliah Fisika Zat Padat mahasiswa non-regular melalui pembelajaran model STAD dengan strategi Self-Explanation. Penelitian ini menggunakan disain kuasi eksperimen rancangan nonequivalent control group design. Hasil penelitian menunjukkan bahwa pembelajaran model STAD dengan strategi Self-Explanation mampu meningkatkan prestasi belajar mahasiswa, yang ditandai oleh gain score ternormalisasi rata-rata kelas eksperimen berturut-turut untuk tes I, II, dan final sebesar 0,567 (kategori medium), 0,783 (kategori tinggi), dan 0,465 (kategori medium) lebih tinggi daripada kelas kontrol sebesar 0,366 (kategori medium), 0,391 (kategori medium), dan 0,340 (kategori medium). Di samping itu, mahasiswa kelas eksperimen memberikan respon positip terhadap proses pembelajaran lebih tinggi daripada kelas kontrol.
\end{abstract}

Kata-kata Kunci: STAD, Self-Explanation, prestasi belajar, Fisika Zat Padat 


\section{PENDAHULUAN}

Matakuliah Fisika Zat Padat (FZP) memiliki bobot 3 sks/3 js dan prasyarat matakuliah Fisika Statistik dan Fisika Kuantum, serta sebagai matakuliah wajib bagi mahasiswa prodi Fisika pada semester keenam (UM, 2013). Matakuliah FZP merupakan prasyarat dari sejumlah matakuliah dalam Kelompok Bidang Keahlian (KBK) Fisika Material, di antaranya Fisika Semikonduktor, Kristalografi, Fisika Keramik, Fisika Magnetik, dan Superkonduktor, yang disajikan pada semester ketujuh dan delapan. Dengan demikian matakuliah FZP merupakan acuan dasar bagi hampir separuh matakuliah dalam KBK Fisika Material.

Pembelajaran matakuliah FZP mulai diupayakan berpusat pada mahasiswa pada perkuliahan tahun 2006/2007, yaitu dengan dikembangkan modul sebagai pendamping diktat kuliah. Karena masih menggunakan metode ceramah, maka pencapaian prestasi belajar mahasiswa pada tahun tersebut belum optimal, yaitu 44,36. Pembelajaran tahun 2007/2008 menggunakan peta konsep dan model pemecahan masalah juga belum mampu mengoptimalkan prestasi belajar mahasiswa. Pembelajaran tersebut hanya mampu memperoleh gain 0,179 kategori rendah dan prestasi belajar 42,44 pada kelas eksperimen; yang tidak berbeda jauh dengan diskusi kelas pada kelas kontrol dengan gain 0,196 kategori rendah dan prestasi belajar 41,42 (Parno, 2009c). Penggunaan model Student Teams Achievements Divisions (STAD) pada pembelajaran tahun 2008/2009 sedikit mengangkat prestasi belajar mahasiswa, yakni 51,77 dan gain 0,48 kategori medium pada kelas eksperimen yang lebih tinggi daripada 44,49 dan gain 0,40 kategori medium pada kelas kontrol. Dengan demikian model pembelajaran pada matakuliah FZP yang lebih banyak lagi melibatkan mahasiswa masih harus terus diupayakan keberadaannya pada pembelajaran berikutnya.
Di samping model pembelajaran, hal penting lain adalah mahasiswa non-regular peserta matakuliah FZP. Sejak saat masuk tahun pertama, mahasiswa non-regular didistribusikan ke dalam kelas tersendiri yang berbeda dengan regular. Tetapi, karena pertimbangan jumlah mahasiswa, maka seringkali offering perkuliahan mahasiswa non-regular dijadikan satu kelas dengan regular. Hal yang demikian diduga dapat menyebabkan prestasi belajarnya masih lebih rendah daripada rerata kelasnya. Misalnya, pada pembelajaran peta konsep dan pemecahan masalah 2007/2008 rerata prestasi belajarnya 38,22 dan gain 0,08 yang masih lebih rendah dari rerata kelas 42,44 dan gain kelas 0,18; dan pada pembelajaran STAD 2008/2009 rerata prestasi belajarnya 42,72 dan gain 0,38 yang masih lebih rendah dari rerata kelas 51,77 dan gain kelas 0,48. Indeks prestasi (IP) mahasiswa non-regular juga masih belum bisa setara dengan regular. Misalnya, mahasiswa non-regular angkatan 2006 memiliki rerata IP semester kelima sebesar 2,61 yang masih lebih rendah daripada regular sebesar 2,76.

Masih belum optimalnya prestasi belajar mahasiswa non-regular di atas, mungkin disebabkan oleh adanya perasaan kurang nyaman saat belajar bersama-sama dengan mahasiswa regular yang dirasakan sebagai bukan kelompoknya. Oleh karena itu ditawarkan alternatif solusinya, yaitu perkuliahan FZP bagi mahasiswa nonregular diselenggarakan melalui offering tersendiri. Di samping itu, juga ditawarkan pembelajaran yang lebih banyak melibatkan mahasiswa, yaitu model pembelajaran STAD dengan strategi belajar Self-Explanation. Sebagai pembanding ditawarkan pembelajaran STAD saja, tanpa menggunakan strategi belajar.

Pembelajaran kooperatif model STAD dapat meningkatkan perasaan positif satu dengan lainnya, mengurangi keterasingan dan kesendirian, membangun hubungan dan menyediakan pandangan positif 
terhadap orang lain. Dalam model STAD kelompok terdiri atas empat mahasiswa yang mewakili keseimbangan kelas dalam kemampuan akademik, jenis kelamin, dan ras. Kelompok merupakan tampilan yang penting dari STAD, dan penting pula bagi dosen dalam rangka mengarahkan anggota masing-masing kelompok (Slavin, 2006). Dalam model STAD terdapat aturan kelompok yang perlu dijelaskan kepada mahasiswa, yaitu (1) para mahasiswa memiliki tanggungjawab bahwa semua anggota kelompoknya telah belajar materi dengan sungguh-sungguh, (2) tak seorangpun selesai belajar sampai semua anggota kelompoknya telah tuntas mempelajari materi, (3) bertanyalah kepada temanmu dalam kelompok sebelum bertanya pada dosen, dan (4) anggota kelompok mendiskusikan materi dengan teman satu kelompok dengan suara yang tidak keras. Aturan kelompok di atas dimaksudkan untuk membangun kebersamaan dan saling kebergantungan positif di antara mereka.

Model STAD memiliki empat fase yang harus dilakukan dalam pembelajaran seperti disajikan dalam tabel berikut (Slavin, 2006).

Tabel 1. Empat Fase dalam Model STAD

\begin{tabular}{ll}
\hline \multicolumn{1}{c}{ Fase } & \multicolumn{1}{c}{ Aktivitas } \\
\hline 1. Presenasi Kelas & $\begin{array}{l}\text { Dosen menyajikan secara langsung tentang materi (konsep, keterampilan, dan kerja ilmiah) } \\
\text { pembelajaran dengan metode ceramah, ceramah dan demonstrasi, atau presentasi } \\
\text { menggunakan audiovisual }\end{array}$ \\
\hline 2. Studi Kelompok & $\begin{array}{l}\text { Anggota kelompok bekerja bersama untuk menyelesaikan lembar kerja yang telah disiapkan dan } \\
\text { dosen perlu memeriksa bahwa setiap anggota kelompok dapat menjawab semua pertanyaan } \\
\text { dalam lembar kerja }\end{array}$ \\
& $\begin{array}{l}\text { Para mahasiswa harus mengatur kursinya sehingga mereka dapat saling berhadapan dalam } \\
\text { kelompoknya }\end{array}$ \\
\hline 3. Pengetesan & $\begin{array}{l}\text { Dosen menyelenggarakan tes secara individu untuk mengukur pengetahuan yang diperoleh } \\
\text { mahasiswa } \\
\text { Skor peningkatan individu akan digunakan untuk menentukan skor peningkatan kelompok }\end{array}$ \\
\hline 4. Penghargaan & $\begin{array}{l}\text { Tahap yang mampu mendorong para mahasiswa untuk lebih kompak, dan penghargaan } \\
\text { diberikan kepada kelompok-kelompok berdasarkan rata-rata peningkatan kelompok, misalnya } \\
\text { dengan sebutan Bintang Sains, Kelompok Enstein, atau sebutan lainnya }\end{array}$ \\
\hline
\end{tabular}

Dari tabel di atas tampak bahwa dalam pembelajaran STAD kelompok berkompetisi dengan kelompok-kelompok lain, mahasiswa dalam satu kelompok bekerja sama untuk menyelesaikan tugas yang telah disiapkan oleh dosen, hasil kerja dan atau penghargaan adalah untuk kelompok bukan untuk perorangan, mahasiswa merasa keberhasilan mereka bergantung pada perilaku dan kinerja mahasiswa lainnya dalam kelompok, efektif dalam mengurangi dominansi mahasiswa yang pintar dalam belajar kelompok, dan dosen memberi umpan balik untuk kelompok. Dengan demikian interaksi dalam kelompok dan antar kelompok lebih efektif dan efisien karena adanya bahan diskusi yang telah dirancang sedemikian rupa oleh dosen dan adanya bimbingan dan arahan dosen secara intensif.

Beberapa penelitian tentang model pembelajaran STAD telah dilakukan. Skor fisika siswa kelas yang diajar dengan model pembelajaran kooperatif model STAD lebih tinggi daripada kelas konvensional (Lamba, 2006). Penggunaan model pembelajaran kooperatif STAD dapat meningkatkan kualitas proses dan hasil belajar kimia siswa (Parlan, 2006). Penggunaan pembelajaran kooperatif model STAD dapat meningkatkan kualitas proses dan hasil belajar kimia organik mahasiswa (Parlan, 2003). Pembelajaran model STAD dapat meningkatkan penguasaan pokok-pokok fisika sekolah mahasiswa dengan gain 0,51 kategori medium untuk kelas eksperimen yang 


\section{ISSN: 2087-9946}

lebih tinggi daripada gain 0,42 kategori medium untuk kelas kontrol (Parno, 2009a). Model STAD dapat meningkatkan gain pretes-postes prestasi belajar Fisika Zat Padat mahasiswa (Parno, 2009b).

Dalam pembelajaran kooperatif, strukturisasi secara hati-hati interaksi antar mahasiswa dapat meningkatkan keluaran pembelajaran (Slavin, 1995). Hal ini menunjukan bahwa pembelajaran kooperatif dengan strategi belajar tertentu dapat meningkatkan keluaran pembelajaran. Arends (1997) menggolongkan strategi belajar menjadi empat bagian besar, yaitu mengulang, elaborasi, organisasi dan metakognisi. Penelitian ini menawarkan strategi belajar metakognisi. Metakognisi berhubungan dengan mahasiswa berpikir tentang berpikir mereka sendiri dan kemampuan mereka dalam memilih strategi belajar terbaik dengan tepat untuk menyelesaikan tugas pembelajaran (Woolfolk, et al., 2008). Metakognisi berkenaan dengan kemampuan untuk merefleksi, memahami, dan mengontrol belajar seseorang (Schraw and Dennison, 1994).

Seperti dihimpun oleh Tajika (2007), banyak penelitian tentang strategi metakognisi yang memfasilitasi pengkonstruksian pengetahuan sehingga mahasiswa dapat memahaminya lebih dalam. Hal senada dikemukakan Garner \& Alexander, dan Presley \& Ghatala, seperti dikutip oleh Schraw \& Dennison (1994), bahwa siswa yang bermetakognisi lebih strategis unjuk kerjanya dibandingkan dengan siswa biasa. Hal ini terjadi karena kesadaran metakognisi siswa akan membimbingnya untuk merencanakan, merangkaikan, dan memonitor belajarnya sedemikian rupa sehingga secara langsung memperbaiki unjuk kerjanya. Menurut Alexander, et al., dan Hattie et al., seperti dikutip oleh Slavin (2006), pengajaran strategi metakognisi terhadap siswa dapat menuju ke arah peningkatan prestasi belajarnya.

Tajika (2007) mengutip pendapat Chi bahwa Self-Explanation merupakan salah satu strategi metakognisi yang efektif karena mahasiswa harus membentuk inferensi yang melebihi informasi yang diberikan. Saat menggunakan strategi tersebut, misalnya dalam menyelesaikan permasalahan fisika, mahasiswa akan menjelaskan permasalahan tersebut kepada dirinya sendiri; atau menjelaskan sistem, prosedur teknik, prinsip, dan konsep permasalahan tersebut ke dalam langkahlangkah problem-solving sendiri mereka (Tajika, 2007). Oleh karena itu penelitian ini menyelenggarakan pembelajaran strategi Self-Explanation yang dileburkan dengan model kooperatif STAD. Menurut psikologi pendidikan dan penelitian pendidikan sains, beberapa praktik pembelajaran sains terbaik, di antaranya yang menganjurkan penggunaan metakognisi, dan menggunakan pembelajaran kooperatif (Wenning, 2003).

Menurut Chi \& VanLehn (1991) SelfExplanation membentuk aktivitas konstruktif, yakni mengharuskan mahasiswa mengemukakan pendapat yang relevan dengan informasi dan bahkan melebihi informasi tersebut. Berarti, SelfExplanation mengintegrasikan konten yang baru dipelajari dengan pengetahuan yang telah ada. Tajika (2007) mengutip pendapat $\mathrm{Chi}$, yaitu karena mahasiswa harus membentuk inferensi yang melebihi informasi yang diberikan, maka SelfExplanation merupakan salah satu strategi metakognisi yang efektif. Dalam penelitiannya, seperti dikutip oleh Tajika (2007), Chi menemukan bahwa mahasiswa yang berkemampuan tinggi cenderung membangun jumlah langkah-langkah SelfExplanation lebih banyak saat mengerjakan permasalahan Mekanika. Tajika (2007) sendiri menemukan bahwa kelas yang diajar dengan strategi SelfExplanation menunjukkan prestasi belajar yang lebih baik daripada kelas kontrol.

Mengacu pada contoh permasalahan mekanika Chi \& VanLehn (1991), berikut disajikan contoh strategi Self-Explanation dalam menyelesaikan permasalahan FZP. 


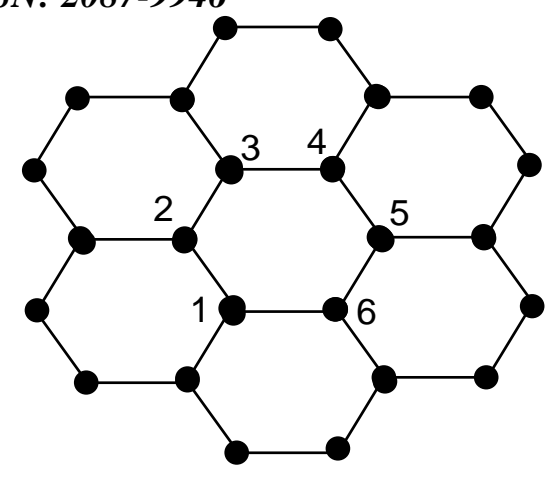

Apakah titik-titik kisi yang membentuk segienam-segienam beraturan yang saling menyambung satu sama lain, seperti gambar, membentuk kisi kristal Bravais?

1. Pola segienam tersebut tampak teratur sehingga membentuk kisi kristal

2. Kisi Kristal harus memenuhi simeteri translasi

3. Seluruh titik kisi yang memenuhi simetri translasi disebut ekivalen

4. Dalam kisi Bravais, seluruh titik kisi adalah ekivalen

5. Bila titik 1 digeser ke titik 3 , atau titik 1 digeser ke titik 5, maka semua titik akan tergeser dan menempati titik lain sehingga tidak menimbulkan pola baru

6. Tetapi, bila titik 1 digeser ke titik 2 , atau titik 1 digeser ke titik 6 , atau titik 1 digeser ke titik 4, maka semua titik akan bisa tergeser untuk menempati titik lain sehingga dapat menimbulkan pola baru

7. Dikatakan bahwa titik-titik tersebut tidak ekivalen

8. Berarti kisi di atas adalah non-Bravais

9. Agar menjadi kisi Bravais, maka dibentuklah basis dari titik-titik tidak ekivalen tersebut

10. Basis adalah kumpulan atom yang ditempatkan di sekitar titik kisi Bravais

11. Jadi kisi di atas adalah kisi Bravais dengan basis dua titik yang tidak ekivalen di atas

Tampak bahwa dalam menyelesaikan permasalahan secara self-explanation di atas mahasiswa menuliskan langkahlangkah problem solving dengan jumlah sebanyak-banyaknya dan serinci-rincinya.
Urutan langkah-langkah problem solving yang jumlahnya banyak dan rinci dalam strategi Self-Explanation di atas dilakukan oleh mahasiswa dalam fase studi kelompok pembelajaran model STAD. Kadang permasalahan diskusi telah diberikan seminggu sebelum pembelajaran agar mahasiswa dapat mempersiapkan langkah-langkah problem solving tersebut secara mandiri. Keadaan yang demikian dapat mengakibatkan kualitas fase studi kelompok meningkat karena menjadi ajang sharing langkah-langkah problem solving Self-Explanation yang telah dipersiapkan oleh setiap mahasiswa anggota kelompok. Pembelajaran yang demikian berpeluang meningkatkan prestasi belajar mahasiswa. Prestasi belajar yang baik dalam matakuliah FZP akan mempertebal persiapan mahasiswa manakala ia berniat mendalami lebih lanjut matakuliahmatakuliah dalam KBK Fisika Material pada semester-semester berikutnya.

\section{METODE PENELITIAN}

Penelitian ini menggunakan disain kuasi eksperimental dengan rancangan nonequivalent control group design (Gall, et al., 2003) seperti tabel berikut.

Tabel 2. Rancangan penelitian

\begin{tabular}{lccc}
\hline Kelompok & $\begin{array}{c}\text { Tes } \\
\text { Awal }\end{array}$ & Perlakuan & $\begin{array}{c}\text { Tes } \\
\text { Akhir }\end{array}$ \\
\hline Eksperimen & $\mathrm{T}_{1}$ & $\mathrm{X}_{1}$ & $\mathrm{~T}_{2}$ \\
\hline Kontrol & $\mathrm{T}_{1}$ & $\mathrm{X}_{2}$ & $\mathrm{~T}_{2}$ \\
\hline
\end{tabular}

Keterangan:

$\mathrm{T}_{1}=$ Tes Awal Prestasi Belajar FZP

$\mathrm{T}_{2}=$ Tes Akhir Prestasi Belajar FZP

$\mathrm{X}_{1}=$ Perlakuan Pembelajaran Model

STAD dengan strategi belajar Self-

Explanation

$\mathrm{X}_{2}=$ Perlakuan Pembelajaran Model

STAD

Rancangan di atas identik dengan pretestposttest experimental control group design dalam eksperimen sejati tetapi tanpa penempatan subjek penelitian secara acak. Subyek penelitian kelas eksperimen adalah 33 mahasiswa non-regular angkatan 
ISSN: 2087-9946

2008/2009 prodi Fisika FMIPA UM, yang sedang mengambil matakuliah FZP pada semester genap 2010/2011. Subyek penelitian kelas kontrol adalah 29 mahasiswa non-regular angkatan 2007/2008 prodi Fisika FMIPA UM, yang sedang mengambil matakuliah FZP pada semester genap 2009/2010.

Berikut dideskripsikan proses pembelajaran model STAD dengan strategi belajar Self-Explanation dalam kelas eksperimen. Pertemuan pertama diisi dengan tes awal, pemaparan tujuan matakuliah FZP, kuliah singkat tentang pembelajaran model STAD dengan strategi Self-Explanation, dan pembentukan kelompok diskusi beranggotakan 4 mahasiswa heterogen berdasarkan IP semester sebelumnya. Pada pertemuan pertama, juga diberikan lembar permasalahan kepada setiap mahasiswa agar di tulis penyelesaiannya secara selfexplanation dalam buku sebagai persiapan dalam fase diskusi kelompok pada pembelajaran minggu berikutnya. Pertemuan kedua dan seterusnya adalah pembelajaran model STAD dengan strategi Self-Explanation: pretes individual 10 butir soal B-S, presentasi materi secara ringkas, diskusi kelompok berpasangan dan dilanjutkan berempat dengan bahan diskusi penyelesaian permasalahan secara self-explanation yang telah ditulis dalam buku oleh setiap mahasiswa anggota kelompok pada minggu sebelum pembelajaran, presentasi kelompok dalam diskusi kelas yang dipimpin oleh dosen, postes individual, dan pemberian penghargaan kelompok sesuai dengan besar peningkatan skor pretes-postes yang dicapai. Pada akhir pembelajaran pada setiap mahasiswa diberikan tugas rumah untuk memperbaiki penyelesaian permasalahan secara self-explanation berdasarkan pembelajaran yang telah dilaksanakan, dan sekaligus diberikan lembar permasalahan sebagai persiapan untuk pertemuan berikutnya. Pada pertemuan terakhir diadakan tes akhir dan penyebaran angket respon mahasiswa terhadap proses pembelajaran.

Deskripsi proses pembelajaran model STAD dalam kelas kontrol sama dengan pembelajaran dalam kelas eksperimen, tetapi tidak menggunakan strategi selfexplanation, dan tidak diberikan lembar permasalahan untuk pertemuan berikutnya. Pertemuan pertama diisi dengan tes awal, pemaparan tujuan matakuliah FZP, kuliah singkat tentang pembelajaran model STAD, dan pembentukan kelompok diskusi beranggotakan 4 mahasiswa heterogen berdasarkan IP semester sebelumnya. Pertemuan kedua dan seterusnya adalah pembelajaran model STAD: pretes individual 10 butir soal B-S, presentasi materi secara ringkas, diskusi kelompok berpasangan dan dilanjutkan berempat dengan bahan permasalahan diskusi 1 lembar per 2 mahasiswa yang telah disiapkan oleh dosen, presentasi kelompok dalam diskusi kelas yang dipimpin oleh dosen, postes individual, dan pemberian penghargaan kelompok sesuai dengan besar peningkatan skor pretes-postes yang dicapai. Pada pertemuan terakhir diadakan tes akhir dan penyebaran angket respon mahasiswa terhadap proses pembelajaran.

Instrumen Tes Prestasi FZP terdiri dari 3 set soal valid dan reliabel berbentuk soal objektif, yakni 30 butir soal Tes I untuk Bab I Struktur Kristal dan Bab II Dinamika Kisi Kristal, 37 butir soal Tes II untuk Bab III Elektron dalam Logam dan Bab IV Teori Pita Energi, dan 29 butir soal Tes Final untuk keempat bab tersebut. Seluruh butir soal memiliki empat jawaban A, B, C, dan D, serta terdiri dari dua jenis, yaitu melengkapi pilihan, dan melengkapi berganda [jawaban A jika (1) dan (2) benar; jawaban B jika (1) dan (3) benar; jawaban C jika (2) dan (3) benar; dan jawaban D jika (1), (2) dan (3) benar]. Karakteristik ketiga instrumen tersebut disajikan dalam tabel berikut. 
ISSN: 2087-9946

Tabel 3. Karakteristik Instrumen Tes I, Tes II, dan Tes Final Matakuliah FZP

\begin{tabular}{clccc}
\hline No & Karakteristik & Tes I & Tes II & $\begin{array}{c}\text { Tes } \\
\text { Final }\end{array}$ \\
\hline 1 & $\begin{array}{l}\text { Jumlah butir } \\
\text { soal }\end{array}$ & 30 & 37 & 29 \\
2 & $\begin{array}{l}\text { Proporsi } \\
\text { ranah tingkat } \\
\text { rendah (C1, }\end{array}$ & $56,67 \%$ & $51,35 \%$ & $55,17 \%$ \\
& C2, dan C3) & & & \\
3 & $\begin{array}{l}\text { Proporsi } \\
\text { ranah tingkat } \\
\text { tinggi (C4, }\end{array}$ & $43,33 \%$ & $48,65 \%$ & $44,83 \%$ \\
& $\begin{array}{l}\text { C5, dan C6) } \\
4\end{array}$ & & & \\
Reliabilitas & 0,799 & 0,892 & 0,750 \\
\hline
\end{tabular}

Intrumen penelitian yang lain adalah Angket Respon Mahasiswa terhadap proses pembelajaran. Angket ini meliputi tiga kategori, dan setiap kategori mengandung sejumlah aspek. Rinciannya adalah kategori A: penilaian terhadap kinerja dosen (aspek penguasaan materi, cara menyampaikan materi, model pembelajaran yang digunakan, sikap di kelas, dan pengelolaan kelas); kategori B: pemahaman mahasiswa terhadap materi (aspek materi lebih mudah dipahami, materi lebih menyenangkan untuk dipelajari, soal-soal tes lebih mudah dikerjakan, dan mahasiswa termotivasi untuk belajar mandiri); dan kategori $\mathrm{C}$ : tanggapan siswa terhadap alat belajar (aspek alat belajar membantu pemahaman materi, dan tersedia untuk semua bab yang dipelajari). Setiap aspek dinyatakan dalam beberapa pernyataan. Mahasiswa dituntut untuk memberikan respon STS (sangat tidak setuju), TS (tidak setuju), S (setuju), atau SS (sangat setuju) terhadap setiap pernyataan.

Teknik analisis terhadap data hasil tes menggunakan gain score ternormalisasi rata-rata, yaitu gain score rata-rata aktual dibagi dengan gain rata-rata aktual maksimum yang mungkin (Hake, 1998).

$\langle g\rangle=\frac{\%\langle\text { gain }\rangle}{\%\langle\text { gain }\rangle_{\max }}=\frac{\%\langle\text { post tes }\rangle-\%\langle\text { pre tes }\rangle}{100-\%\langle\text { pre tes }\rangle}$

Klasifikasi peningkatan prestasi belajar mahasiswa ditandai oleh besarnya $\langle\mathrm{g}\rangle$, yakni tinggi jika lebih besar daripada 0,7 ; medium jika antara 0,3 sampai dengan 0,7; dan rendah jika lebih kecil daripada 0,3. Pembelajaran model STAD dengan strategi Self-Explanation dikatakan dapat meningkatkan prestasi belajar mahasiswa apabila gain score ternormalisasi rata-rata kelas ekperimen lebih tinggi daripada kelas kontrol.

Terhadap data hasil angket respon mahasiswa terhadap proses pembelajaran dilakukan analisis kuantitatif, yaitu mencari rata-rata dari seluruh nilai butir pernyatan angket, dengan kriteria pembelajaran model STAD dengan strategi Self-Explanation maupun STAD sendiri mendapatkan respon positip dari mahasiswa jika pilihan jawaban SS (sangat setuju) dan $\mathrm{S}$ (setuju) oleh mahasiswa melebihi 50\% (Ubaya, 2006). Disamping itu juga dikemukakan respon negatip mahasiswa, yaitu jika jawaban STS (sangat tidak setuju) dan TS (tidak setuju) oleh mahasiswa melebihi $20 \%$.

\section{HASIL DAN PEMBAHASAN}

Berikut dideskripsikan proses pembelajaran matakuliah FZP semester II 2010/2011 yang menggunakan model STAD dengan strategi Self-Explanation pada kelas eksperimen. Pembelajaran kelas eksperimen berlangsung setiap hari Jumat jam ke-1 s/d 3 dengan rincian berikut.

- Pertemuan 1: Tes awal, pemaparan tujuan matakuliah FZP, kuliah singkat tentang pembelajaran model STAD dengan strategi Self-Explanation, dan pembentukan kelompok diskusi beranggotakan 4 mahasiswa heterogen berdasarkan IP semester sebelumnya, serta di akhir pertemuan diberikan lembar permasalahan kepada setiap mahasiswa agar di tulis penyelesaiannya secara self-explanation dalam buku sebagai persiapan dalam diskusi kelompok pada pembelajaran minggu berikutnya.

- Pertemuan 2 s/d 8: Pembelajaran model STAD dengan strategi Self-Explanation 
untuk Bab I dan Bab II. Pretes mengawali pembelajaran ini, dilanjutkan dengan presentasi singkat materi, diskusi kelompok dengan bahan diskusi penyelesaian permasalahan secara self-explanation yang telah ditulis dalam buku oleh setiap mahasiswa anggota kelompok pada minggu sebelum pembelajaran dengan pola diskusi berpasangan dilanjutkan dengan diskusi berempat, tes individu, dan penghargaan kelompok. Pada akhir pembelajaran pada setiap mahasiswa diberikan tugas rumah untuk memperbaiki penyelesaian permasalahan secara self-explanation berdasarkan pembelajaran yang telah dilaksanakan, dan sekaligus diberikan lembar permasalahan sebagai persiapan untuk pertemuan berikutnya.

- Pertemuan 9: Tes I dan penyebaran angket respon mahasiswa tentang proses pembelajaran periode pertama.

- Pertemuan 10 s/d 13: Pembelajaran model STAD dengan strategi SelfExplanation untuk Bab III dan Bab IV dengan pola yang sama dengan Bab I dan Bab II di atas.

- Pertemuan 14: Tes II dan penyebaran angket respon mahasiswa tentang proses pembelajaran periode kedua.

- Pertemuan 15: Tes Final

Proses pembelajaran model STAD dalam matakuliah FZP semester II 2009/2010 pada kelas kontrol dideskrip- sikan sebagai berikut. Perkuliahan berlangsung setiap hari Senin jam ke-1 s/d 3 dengan rincian berikut.

- Pertemuan 1: Tes awal, pemaparan tujuan matakuliah FZP, kuliah singkat tentang pembelajaran model STAD, dan pembentukan kelompok diskusi beranggotakan 4 mahasiswa heterogen berdasarkan IP semester sebelumnya.

- Pertemuan 2 s/d 8: Pembelajaran model STAD. Pretes mengawali pembelajaran ini, dilanjutkan dengan presentasi singkat materi, diskusi kelompok dengan bahan yang telah disiapkan dosen dengan pola diskusi berpasangan dilanjutkan dengan diskusi berempat, tes individu, dan penghargaan kelompok.

- Pertemuan 9: Tes I dan penyebaran angket respon mahasiswa tentang proses pembelajaran periode pertama.

- Pertemuan 10 s/d 13: Pembelajaran model STAD untuk Bab III dan Bab IV dengan pola yang sama dengan Bab I dan Bab II di atas.

- Pertemuan 14: Tes II dan penyebaran angket respon mahasiswa tentang proses pembelajaran periode kedua.

- Pertemuan 15: Tes Final

Berikut disajikan ringkasan hasil tes prestasi FZP yang dicapai mahasiswa prodi Fisika dari kelas eksperimen dan kontrol.

Tabel 4. Ringkasan Hasil Statistik Tes I, Tes II, dan Tes Final Matakuliah FZP Mahasiswa dari Kelas Eksperimen dan Kontrol

\begin{tabular}{|c|c|c|c|c|c|c|c|c|c|c|}
\hline \multirow[b]{2}{*}{ No } & \multirow[b]{2}{*}{ Ke-las } & \multicolumn{3}{|c|}{ Tes I } & \multicolumn{3}{|c|}{ Tes II } & \multicolumn{3}{|c|}{ Tes Final } \\
\hline & & $\begin{array}{c}\text { Rerata } \\
\text { tes } \\
\text { awal }\end{array}$ & $\begin{array}{c}\text { Rerata } \\
\text { tes } \\
\text { akhir }\end{array}$ & $\begin{array}{l}\text { Pening- } \\
\text { katan }\end{array}$ & $\begin{array}{c}\text { Rerata } \\
\text { tes } \\
\text { awal }\end{array}$ & $\begin{array}{l}\text { Rerata } \\
\text { tes } \\
\text { akhir }\end{array}$ & $\begin{array}{l}\text { Pening- } \\
\text { katan }\end{array}$ & $\begin{array}{c}\text { Rerata } \\
\text { tes } \\
\text { awal }\end{array}$ & $\begin{array}{c}\text { Rerata } \\
\text { tes } \\
\text { akhir }\end{array}$ & $\begin{array}{l}\text { Pening- } \\
\text { katan }\end{array}$ \\
\hline 1 & Kontrol & 8,7 & 42,1 & 33,4 & 10,5 & 45,5 & 35,0 & 8,6 & 39,7 & 31,1 \\
\hline 2 & Eksperimen & 14,6 & 63,0 & 48,4 & 5,4 & 79,5 & 74,1 & 10,3 & 52,1 & 41,8 \\
\hline
\end{tabular}

Dari tabel di atas tampak bahwa perolehan rata-rata kelas eksperimen berturut-turut untuk tes I, II, dan final, yaitu 63,0, 79,5, dan 52,1 lebih tinggi daripada kelas kontrol berturut-turut 42,1, 45,5, dan 39,7. Begitu pula besar peningkatannya, berturut-turut untuk tes I, II, dan final, yaitu 48,4, 74,1, dan 41,8 untuk kelas 
eksperimen dan berturut-turut 33,4, 35,0, dan 31,1 untuk kelas kontrol. Dengan demikian perlakuan pada kelas eksperimen, yaitu pembelajaran model STAD dengan strategi Self-Explanation, mampu meningkatkan prestasi belajar FZP mahasiswa lebih baik daripada perlakuan pada kelas kontrol, yaitu pembelajaran model STAD saja tanpa strategi belajar.

Perolehan rata-rata mahasiswa nonregular pada kelas kontrol untuk tes I, yaitu sebesar 42,1 ternyata hampir sama dengan prestasi belajar dalam menempuh matakuliah FZP pada pembelajaran tahun 2008/2009 sebelumnya, yaitu sebesar 42,72. Kesejajaran perolehan prestasi belajar ini adalah wajar karena kedua kelas menggunakan model pembelajaran yang sama, yaitu STAD. Tetapi, pembelajaran model STAD ini masih lebih mampu meningkatkan prestasi belajar mahasiswa non-regular daripada pembelajaran model pemecahan masalah dengan tugas peta konsep pada 2007/2008 sebelumnya, yang hanya sebesar 38,22. Dengan demikian perolehan rerata tes I sebesar 63,0 untuk kelas eksperimen yang lebih tinggi daripada 42,1 untuk kelas kontrol di atas, jelas merupakan indikasi bahwa pembelajaran model STAD dengan strategi Self-Explanation mampu meningkatkan prestasi belajar FZP.

Prestasi belajar FZP mahasiswa nonregular dalam penelitian ini jauh melebihi yang sebelumnya yang menggabung mahasiswa nonregular dan regular dalam offering kelas yang sama. Perolehan rerata tes I kelas eksperimen mahasiswa nonregular yang menggunakan model STAD dengan strategi SelfExplanation sebesar 63,0 pada semester II 2010/2011 jauh lebih tinggi daripada prestasi belajar mahasiswa gabungan nonregular dan regular sebesar 51,77 dalam pembelajaran STAD 2008/2009 dan sebesar 42,44 dalam pembelajaran peta konsep dan pemecahan masalah 2007/2008. Hal ini berarti solusi perkuliahan FZP bagi mahasiswa nonregular diselenggarakan melalui offering tersendiri dan dengan melibatkan mahasiswa lebih banyak dalam pembelajaran model STAD dengan strategi Self-Explanation adalah tepat.

Perbedaan perolehan gain ternormalisasi rata-rata $\langle\mathrm{g}\rangle$ dari kelas eksperimen dan kontrol disajikan dalam tabel berikut

Tabel 5. Perolehan Gain Rata-Rata $<\mathrm{g}>$ dari Kelas Eksperimen dan Kontrol

\begin{tabular}{ccccc}
\hline No & Kelas & Gain Tes I (Klasifikasi) & Gain Tes II (Klasifikasi) & Gain Tes Final (Klasifikasi) \\
\hline 1 & Kontrol & 0,366 (Medium) & 0,391 (Medium) & 0,340 (Medium) \\
2 & Eksperimen & 0,567 (Medium) & 0,783 (Tinggi) & 0,465 (Medium) \\
\hline
\end{tabular}

Senada dengan pembahasan prestasi belajar di atas, yaitu khusus untuk tes I, perolehan gain model STAD kelas kontrol sebesar 0,366 tidak berbeda jauh dengan perolehan pembelajaran yang sama pada tahun sebelumnya, yaitu sebesar 0,38. Tetapi, secara keseluruhan tampak bahwa gain ternormalisasi rata-rata kelas eksperimen [berturut-turut untuk tes I, II, dan final sebesar 0,567 (Medium), 0,783 (Tinggi), dan 0,465 (Medium)] lebih tinggi daripada kelas kontrol [berturut-turut sebesar 0,366 (Medium), 0,391 (Medium), dan 0,340 (Medium)]. Perbandingan harga gain ini lebih menguatkan perolehan penelitian bahwa pembelajaran model STAD dengan strategi Self-Explanation pada kelas eksperimen mampu meningkatkan prestasi belajar mahasiswa yang lebih baik daripada pembelajaran yang hanya menggunakan model STAD saja tanpa strategi belajar pada kelas kontrol. Bahkan, khusus untuk tes II, kelas eksperimen dapat mencapai gain ternormalisasi rata-rata dalam klasifikasi peningkatan yang berkategori Tinggi, yang 
setingkat lebih tinggi daripada kelas kontrol yang berkategori Medium. Hal yang demikian sesuai dengan yang dikutip oleh Slavin (2006), bahwa pengajaran strategi metakognisi terhadap siswa dapat menuju ke arah peningkatan prestasi belajarnya. Perolehan gain pada kelas eksperimen di atas sudah melampaui batas rerata gain yang biasa dicapai dalam pembelajaran yang melibatkan mahasiswa aktif, yakni sebesar 0,48 (Jackson, et al., 2008).

Gain tes I model STAD dengan strategi Self-Explanation kelas eksperimen mahasiswa nonregular sebesar 0,567 juga jauh lebih tinggi daripada gain model STAD mahasiswa gabungan nonregular dan regular sebelumnya yang hanya 0,48 . Hal ini memperkuat fakta bahwa perkuliahan FZP bagi mahasiswa nonregular memang harus diselenggarakan melalui offering tersendiri.

Peningkatan prestasi belajar mahasiswa pada matakuliah FZP di atas diduga disebabkan oleh hal-hal berikut. Mahasiswa kelas eksperimen tampak percaya diri sehingga memiliki motivasi belajar tinggi saat pembelajaran berlangsung. Hal ini terjadi karena mahasiswa telah memiliki persiapan yang baik berupa langkah-langkah problem solving permasalahan yang ditulis secara self-explanation sejak seminggu sebelumnya. Dalam kelompok terjadi sharing langkah-langkah problem solving tersebut antar mahasiswa anggota kelompok. Hal yang demikian sesuai dengan yang dikutip oleh Schraw \& Dennison (1994), bahwa siswa yang bermetakognisi lebih strategis unjuk kerjanya dibandingkan dengan siswa biasa. Dalam fase diskusi kelompok terjadi transfer pengetahuan yang sangat instensif dari mahasiswa yang berkemampuan lebih tinggi kepada mahasiswa yang berkemam- puan sedang dan rendah. Hal ini terjadi karena mahasiswa yang berkemampuan tinggi cenderung membangun jumlah langkah-langkah Self-Explanation lebih banyak saat mengerjakan permasalahan fisika (Tajika, 2007). Hal ini diperkuat lagi dengan adanya presentasi kelompok dalam diskusi kelas yang dipimpin langsung oleh dosen pembina. Tugas rumah memperbaiki langkah-langkah problem solving tersebut setelah pembelajaran makin menyempur-nakan pemahaman mahasiswa terhadap permasalahan FZP yang sedang dipelajari. Sementara itu, mahasiswa kelas kontrol tampak memiliki motivasi yang belum optimal karena lembar permasalahan baru diberikan oleh dosen pembimbing saat diskusi kelompok berlangsung. Hal ini menyebabkan persiapan mahasiswa kurang sehingga diduga konsentrasinya tidak konstan saat mengikuti diskusi kelompok. Dengan demikian perlakuan model STAD dengan strategi Self-Explanation pada kelas eksperimen perlu dipertahankan dan lebih disempurnakan lagi dalam pembelajaran matakuliah FZP.

Pembelajaran model STAD dengan strategi Self-Explanation dapat meningkatkan prestasi belajar mahasiswa. Hasil penelitian ini mendukung hasil penelitian serupa sebelumnya, yaitu seperti dihimpun oleh Tajika (2007) bahwa banyak penelitian tentang strategi metakognisi yang memfasilitasi pengkonstruksian pengetahuan sehingga mahasiswa dapat memahaminya lebih dalam; dan Tajika (2007) sendiri menemukan bahwa kelas yang diajar dengan strategi Self-Explanation menunjukkan prestasi belajar yang lebih baik daripada kelas kontrol.

Hasil analisis statistik respon mahasiswa terhadap pembelajaran disajikan dalam tabel berikut. 
Tabel 6. Respon SS (sangat setuju) dan S (setuju) Mahasiswa terhadap Proses Pembelajaran dari Kelas Eksperimen dan Kontrol

\begin{tabular}{|c|c|c|c|c|c|c|c|c|c|}
\hline \multirow[t]{2}{*}{ No } & \multirow[t]{2}{*}{ Kelas } & \multicolumn{4}{|c|}{$\begin{array}{l}\text { \% Pembelajaran Periode Pertama (Bab I } \\
\text { dan Bab II) }\end{array}$} & \multicolumn{4}{|c|}{$\begin{array}{l}\text { \% Pembelajaran Periode Kedua (Bab III dan } \\
\text { Bab IV) }\end{array}$} \\
\hline & & $A$ & $B$ & C & Total & $A$ & $B$ & C & Total \\
\hline 1 & Kontrol & 90,01 & 87,02 & 81,91 & 89,65 & 86,97 & 81,88 & 83,82 & 84,22 \\
\hline 2 & Eksperimen & 93,90 & 92,94 & 89,91 & 92,18 & 92,66 & 89,15 & 83,09 & 88,30 \\
\hline
\end{tabular}

Dari tabel di atas tampak bahwa respon mahasiswa adalah positip (lebih dari 50\% mahasiswa menyatakan sangat setuju dan setuju) terhadap proses pembelajaran matakuliah FZP, baik pada kelas ekperimen $(92,18 \%$ periode pertama, dan $88,30 \%$ periode kedua) maupun kelas kontrol $(89,65 \%$ periode pertama, dan $84,22 \%$ periode kedua). Tampak bahwa kelas eksperimen memiliki respon lebih tinggi daripada kelas kontrol hampir pada semua aspek A, B, maupun C. Respon yang lebih baik dalam diri mahasiswa kelas eksperimen mungkin disebabkan oleh rasa percaya diri dan motivasinya yang tinggi selama pembelajaran seperti yang telah dijelaskan di atas. Respon yang lebih baik tersebut menunjukkan bahwa pembelajaran dengan model STAD dengan strategi Self-Explanation pada kelas eksperimen dirasakan lebih nyaman daripada pembelajaran yang hanya menggunakan model STAD saja tanpa strategi belajar pada kelas kontrol oleh mahasiswa. Hal ini pula yang diduga menyebabkan prestasi belajar mahasiswa kelas eksperimen lebih tinggi daripada kelas kontrol.

Mahasiswa kelas eksperimen merasa belajar lebih nyaman selama pembelajaran berlangsung daripada kelas kontrol juga ditunjukkan oleh responnya terhadap beberapa pernyataan. Jika dilihat dari beberapa pernyataan dalam angket, mahasiswa kelas eksperimen menunjukkan respon negatip (lebih dari 20\% sangat tidak setuju dan tidak setuju) lebih sedikit daripada kelas kontrol. Kelas eksperimen hanya memberikan respon negatip pada satu pernyataan, yaitu soal-soal tes mudah saya kerjakan. Tetapi, kelas kontrol memberikan respon negatip pada tiga pernyataan, yaitu model yang digunakan bersifat menantang, sehingga mendorong mahasiswa untuk melakukan aktivitas secara sungguh-sungguh dan antusias; mahasiswa menemukan sendiri konsep yang dipelajari dengan melakukan pengujian hipotesis/dugaan; dan soal-soal tes mudah saya kerjakan. Di samping itu, kenyamanan mahasiswa kelas eksperimen dalam belajar juga ditunjukkan oleh respon negatip mahasiswa kelas kontrol yang relatif lebih tinggi daripada kelas ekeprimen, meskipun tidak melebihi $20 \%$, terhadap beberapa pernyataan, yaitu dosen menjawab pertanyaan mahasiswa secara jelas sesuai dengan maksud pertanyaan mahasiswa; dosen melakukan demonstrasi/ menunjukkan gejala fisis untuk mengarahkan perhatian mahasiswa; pembelajaran menyenangkan; mahasiswa tidak takut mengekspresikan kegembiraan, misalnya dengan bertepuk tangan; dan pembelajaran yang dilakukan dosen lebih menarik dan memotivasi mahasiswa untuk belajar.

\section{KESIMPULAN DAN SARAN}

Berdasarkan hasil penelitian dan pembahasan di atas, maka dapat disimpulkan pembelajaran FZP berikut. (1) Deskripsi proses pembelajaran model STAD dengan strategi Self-Explanation dengan alokasi waktu 3 js/minggu adalah (a) pertemuan awal: tes awal, pemaparan tujuan matakuliah, kuliah singkat tentang pembelajaran model STAD dengan strategi Self-Explanation dan pembentukan kelompok heterogen; dan pemberian lembar permasalahan agar di tulis langkahlangkah problem solvingnya secara selfexplanation sebagai persiapan dalam 


\section{ISSN: 2087-9946}

pembelajaran minggu berikutnya; (b) pembelajaran model STAD dengan strategi Self-Explanation; dan (c) pertemuan akhir: tes akhir dan penyebaran angket respon mahasiswa.

Pembelajaran model STAD dengan strategi Self-Explanation mampu meningkatkan prestasi belajar mahasiswa, yang ditandai oleh gain score ternormalisasi rata-rata kelas eksperimen berturut-turut untuk tes I, II, dan final sebesar 0,567 (kategori medium), 0,783 (kategori tinggi), dan 0,465 (kategori medium) lebih tinggi daripada kelas kontrol sebesar 0,366 (kategori medium), 0,391 (kategori medium), dan 0,340 (kategori medium). (3) Mahasiswa kelas eksperimen memberikan respon positip lebih tinggi daripada kelas kontrol terhadap proses pembelajaran.

Hasil penelitian ini, setidaknya, dapat dimanfaatkan oleh beberapa pihak, yaitu dosen, mahasiswa, dan pengelola prodi fisika. Mahasiswa prodi Fisika dapat menggunakan strategi belajar SelfExplanation selama mengikuti pembelajaran sebagai salah satu upaya untuk terus meningkatkan prestasi belajarnya. Prestasi belajar yang baik dalam matakuliah FZP akan mempertebal persiapan mahasiswa manakala ia berniat mendalami lebih lanjut matakuliahmatakuliah dalam KBK Fisika Material pada semester-semester berikutnya. Dosen pembina matakuliah FZP dapat menggunakan pembelajaran model STAD dengan strategi Self-Explanation sebagai salah satu pijakan dalam pembelajaran yang akan datang. Pengelola prodi fisika dapat menyelenggarakan perkuliahan FZP dalam offering tersendiri khusus bagi mahasiswa non-regular dengan menerapkan pembelajaran model STAD dengan strategi Self-Explanation.

\section{DAFTAR RUJUKAN}

Arends, R.I. 1997. Classroom Instruction and Management. New York: The McGraw-Hill Companies, Inc.
Chi, M.T.H., VanLehn, K.A. 1991. "The Content of Physics Self-Explanations". THE JOURNAL OF THE LEARNING SCIENCES 1 (1) 69-105

Gall, M.D., Gall, J.P., and Borg, W.R. 2003. Educational Research: An Introduction. Boston: Allyn and Bacon Jackson, J., Dukerich, L., and Hestenes, D. 2008. "Modeling Instruction: An Effective Model for Science Education". Science Educator. Vol. 17. No. 1. Spring 2008 pp. 10-17

Hake, R. 1998. "Interactive-engagement vs traditional methods: a six-thousandstudent survey of mechamics test data for introductory physics courses". Am. J, Phys. 64-74.

Lamba, H.A. 2006. "Pengaruh Pembelajaran Kooperatif Model STAD dan Gaya Kognitif Terhadap Hasil Belajar Fisika Siswa SMA". Jurnal Ilmu Pendidikan Jilid 13, Nomor 2, Juni 2006.

Parlan. 2003. Penggunaan Model Pembelajaran Kooperatif (Cooperative Learning) Tipe STAD untuk Meningkatkan Kualitas Proses dan Hasil Belajar Kimia Organik III Mahasiswa Jurusan Kimia FMIPA Universitas Negeri Malang. Laporan Penelitian tidak diterbitkan. Malang: Lembaga Penelitian Universitas Negeri Malang.

Parlan. 2006. Penggunaan Model Pembelajaran Kooperatif STAD untuk Meningkatkan Kualitas Proses dan Hasil Belajar Kimia Kelas X SMAN 9 Malang. Laporan Penelitian tidak diterbitkan. Malang: Lembaga Penelitian Universitas Negeri Malang.

Parno. 2009a. "Pengaruh STAD terhadap Peningkatan Kemampuan Mahasiswa Menguasai Materi Fisika Sekolah". Jurnal Pendidikan Matematika dan Sains (JPMS) FMIPA Universitas Negeri Yogyakarta. Volume 14, Nomor 2, November 2009.

Parno. 2009b. "Peningkatan Gain Score Pretes-Postes Prestasi Belajar Fisika Zat Padat Mahasiswa Melalui Model 
STAD dalam Kegiatan Lesson Study". Makalah disajikan dalam Seminar Nasional ke 2 Lesson Study: Perkembangan Innovási Pembelajaran melalui Lesson Study dan Dampaknya terhadap Peningkatan Mutu Pendidikan di Indonesia di FMIPA Universitas Negeri Malang pada 17 Oktober 2009.

Parno. 2009c. "Pengaruh Pembelajaran Menggunakan Peta Konsep dan Model Pemecahan Masalah terhadap Peningkatan Prestasi Belajar Fisika Zat Padat Mahasiswa”. Jurnal Penelitian Pendidikan MATEMATIKA DAN SAINS. FMIPA UNESA. Vol. 16, No. 2, Desember 2009

Schraw, G. and Dennison, R.S. 1994. "Assessing Metacognitive Awareness". Contemporary Educational Psychology, 19, 460-475

Slavin, R.E. 1995. Cooperative Learning: Theory, Research, and Practice 2nd ed. Boston: A Simon \& Schuster Company
Slavin, R.E. 2006. Educational Psychology: Theory and Practice (8-th Edition). Boston: Pearson.

Tajika, H., Nakatsu, N., Nozaki, H., Neumann, E., Maruno, S. 2007. "Effects of Self-Explanation as A Metacognitive Strategy for Solving Mathematical Word Problems". Japanese Psychological Research (2007), Volume 49, No. 3, 222-233

Ubaya. 2006. Panduan Pelaksanaan kegiatan dan Sistem Evaluasi HPKP SMA 2006.

UM. 2013. Katalog FMIPA UM: Jurusan Fisika (Edisi 2013). Malang: FMIPA Universitas Negeri Malang.

Wenning, C.J. 2003. "Change principles for departmentally-based physics teacher education programs". JOURNAL OF PHYSICS TEACHER EDUCATION ONLINE Vol. 2, No. 1 September 2003 pp. 7-12

Woolfolk, A, Hughes, M, and Walkup, V. 2008. Psychology in Education. New York: Pearson Longman 